\title{
Low back pain and disability in military police: an epidemiological study
}

\author{
Dor lombar e incapacidade em policiais \\ militares: um estudo epidemiológico
}

\section{Dolor lumbar e incapacidad en policías militares: un estudio epidemiológico}

\section{Edeildo Simplício Cardoso, Sabrina Gabrielle Gomes Fernandes, Luana Caroline de Assunção Cortez Corrêa, Glauko André de Figueirêdo Dantas, Saionara Maria Aires da Câmara*}

[a] Universidade Federal do Rio Grande do Norte (UFRN), Santa Cruz, RN, Brazil

\begin{abstract}
Introduction: The low back pain is a major public health problem in industrialized societies, commonly affecting the adult population. The occupation is considered as a risk factor, especially those functions that require physical effort, we have as example the job of the military police, who are exposed to several risk factors, both those who perform administrative activities, and those who perform the ostensive policing. Objective: The aim of this study was to evaluate the prevalence of low back pain among military police, as
\end{abstract}

*ESC: undergrad, e-mail: edeildo-simplicio@hotmail.com SGGF: Master's student, e-mail: sabrinaggf@hotmail.com LCACC: Master's student, e-mail: lu_cortez_29@hotmail.com GAFD: MS, e-mail: glauko.ft.andre@hotmail.com

SMAC: PhD, e-mail: saionaraaires@gmail.com 
well the presence of disability and associated factors. Methods: This is an analytical cross-sectional study. Was evaluated the level of disability, pain before and after the work shift, flexibility, postural alterations and anthropometric measures. It was used the regression analysis, considering 95\% CI and $\mathrm{p}<0.05$. Were interviewed 97 military police with mean age of 39.30 ( \pm 5.33 ), all males. Results: The complaint of low back pain was significantly larger after the work shift, and $82.5 \%$ reported difficulties in daily life activities due to low back pain. Conclusion: There is a high prevalence of low back pain and impairment in daily life activities because of military police. The data presented reinforce the need to consider low back pain as a public health problem that affects the whole population, especially the military police.

Keywords: Low Back Pain. Epidemiology. Occupational Health. Military Personnel.

\section{Resumo}

Introdução: A dor na região lombar é um importante problema de saúde pública nas sociedades industrializadas, acometendo comumente a população adulta. A ocupação é considerada como um fator de risco, principalmente aquelas funções que requerem esforço físico, temos como exemplo a ocupação do policial militar, que se encontram expostos a vários fatores de risco, tanto os que realizam atividades administrativas, quanto àqueles que realizam o policiamento ostensivo. Objetivo: Avaliar a prevalência de dor lombar entre policiais militares, bem como a presença de incapacidade e seus fatores associados. Métodos: Trata-se de um estudo transversal de caráter analítico. Foi avaliado o nível de incapacidade, dor antes e depois do turno de trabalho, flexibilidade, alterações posturais e medidas antropométricas. Utilizou-se a análise de regressão linear múltipla, considerando o IC 95\% e p $<$ 0,05. Foram entrevistados 97 policiais militares com média de idade de 39,30 ( \pm 5,33), sendo todos do sexo masculino. Resultados: A queixa de dor lombar foi significativamente maior após o turno de trabalho e, 82,5\% dos indivíduos relataram prejuízo na realização das atividades da vida diária decorrente de lombalgia. Conclusão: Há uma alta prevalência de dor lombar e prejuízo nas atividades da vida diária em sua decorrência entre os policiais militares. Os dados apresentados reforçam a necessidade de considerar a lombalgia como problema de saúde pública que afeta toda a população, em especial os policiais militares.

Palavras-chave: Dor Lombar. Epidemiologia. Saúde do Trabalhador. Militares.

\section{Resumen}

Introducción: El dolor en la región lumbar es un importante problema de salud pública en las sociedades industrializadas, afectando comúnmente a la población adulta. La ocupación es considerada como un factor de riesgo, principalmente aquellas funciones que requieren esfuerzo físico, tenemos como ejemplo la ocupación del policía militar, que se encuentran expuestos a varios factores de riesgo, tanto los que realizan actividades administrativas, como los que realizan el trabajo policial ostensible. Objetivo: El objetivo de este estudio fue evaluar la prevalencia de dolor lumbar entre policías militares, así como la presencia de incapacidad y sus factores asociados. Métodos: Se trata de un estudio transversal de carácter analítico. Se evaluó el nivel de incapacidad, dolor antes y después del turno de trabajo, flexibilidad, alteraciones posturales y medidas antropométricas. Se utilizó el análisis de regresión lineal múltiple considerando el IC 95\% y p < 0,05. Se entrevistaron a 97 policías militares con una media de edad de 39,30 ( \pm 5,33), siendo todos del sexo masculino. Resultados: La queja de dolor lumbar fue significativamente mayor después del turno de trabajo y el 82,5\% de los individuos reportaron perjuicio en la realización de las actividades de la vida diaria derivada de la lumbalgia. Conclusión: Se concluye que hay una alta prevalencia de dolor lumbar y perjuicio en las actividades de la vida diaria en su consecuencia entre los policías militares. Los datos presentados refuerzan la necesidad de considerar la lumbalgia como problema de salud pública que afecta a toda la población, en especial a los policías militares.

Palabras clave: Dolor de la Región Lumbar. Epidemiología. Salud Laboral. Personal Militar. 


\section{Introduction}

Low back pain is an important public health concern that often affects the adult population in industrialized societies $[1,2]$. Its incidence is only outranked by headaches on the scale of painful disorders affecting people, being a frequent cause of disturbance in physical functions, disability, limitations in activities and restrictions in social participation [3 - 5].

Cross-sectional epidemiological studies have estimated an annual prevalence rate of approximately $50 \%$ in the Brazilian population, affecting mainly men over 40 years old and women between the ages of 50 and 60 years old [6]. According to data from the National School of Health, it is estimated that $70 \%$ to $85 \%$ of the population have had or will have an episode of low back pain in their life-course [7].

Studies show that the main individual and psychosocial risk factors for low back pain are gender, age, body mass index (BMI), genetics, stress, anxiety and depression [5, 8]. Occupation is also considered a risk factor, especially those requiring physical effort such as lifting, pulling and pushing weights, as well as repetitive activities, inadequate maintained postures, vehicle vibration, several hours of work and work shifts $[5,9,10]$.

In the occupation of police officer, several factors expose the officers to risk, both for those who carry out administrative activities and those who carry out ostensive policing. When performing their jobs, the police officers may work for periods of six hours of work, twelve hours or twenty-four hours a day [11], frequently staying for long periods in the same orthostatic or sedentary position and using heavy equipment such as uniforms, weaponry, chargers, handcuffs and radio transmitters $[12,13]$.

According to a study by Vasconcelos [14], one item that is considered to be responsible for causing pain in police officers is the bullet-proof vest, since this equipment varies between $1.1 \mathrm{~kg}$ in size $\mathrm{P}$, reaching a maximum weight of $2.6 \mathrm{~kg}$ in the largest size [14].

Therefore, the present study aims to identify the prevalence of low back pain among police officers, as well as to identify the proportion of them presenting impairments in daily living activities due to low back pain and which factors are associated to it.

\section{Methods}

\section{Study type and sample}

This is an analytical cross-sectional study. This research received ethics approval by the Ethics and Research Committee of the Faculty of Health Sciences of Trairi (FACISA/UFRN), with approval number 1,475,474. All participants signed the consent form according to the norms of the National Health Council, Resolution no 466/2012.

The sample consisted of police officers who were active in the $8^{\text {th }}$ Military Police Battalion ( $8^{\text {th }}$ MPB) of Rio Grande do Norte state, located in the municipality of Nova Cruz in the Agreste Potiguar region. Such individuals are allocated to diverse sectors that include ostensive activity to administrative functions.

To carry out data collection, the researchers visited 11 of the 27 municipalities that are under the responsibility of the $8^{\text {th }}$ MPB. One hundred and twenty (120) police officers were contacted and invited to participate, and 97 of them agreed to participate. Data collection was carried out from June to October 2016.

\section{Instruments}

A previously-trained Physiotherapy student for this research protocol evaluated all subjects using a structured questionnaire containing data on age, gender, schooling, income, ethnicity and information about their work.

The interviewer subsequently applied the Oswestry Disability Index (ODI), adapted and validated for the Brazilian population [15], in order to evaluate disability due to low back pain. The questionnaire contains 10 sections and there are six statements ranging from 0 to 5 points for each of them, and the respondent should identify which one represents their condition in a given situation. Intermediate statements are scored according to this grade. If more than one statement is indicated in each section, the highest value is scored. To quantify the result, it is necessary to divide the value found by the sum of scores in all sections by the maximum value of the questionnaire, which is equal to 50 . The result is then multiplied by 100 and expressed as a percentage. The degree of disability can be classified as minimal $(0$ $20 \%$ ); moderate (21 - 40\%); severe (41 - 60\%); crippled (61 - 80\%) or a bed-ridden individual (81 - 100\%) [16] . 
To assess the pain and its intensity before and after the work shift, we used the numerical rating scale for pain which consists of a ruler containing 11 spaces numbered successively from 0 to 10 . The subject then refers to the equivalence between the intensity of his/ her pain and a numerical classification, with 0 being "NO PAIN" and 10 "MAXIMUM PAIN" [17].

All participants were assessed in relation to weight (kg) using a Taurus 150kg XY 6091 Kikos $^{\circledR}$ scale, and height $(\mathrm{m})$ with an anthropometric measurement tape of fiber glass with lock (Shopfisio ${ }^{\circledR}$ ). Both measures were used to calculate Body Mass Index (BMI - $\left.\mathrm{kg} / \mathrm{m}^{2}\right)$.

Flexibility was assessed by the fingertip-to-floor test [18]. Participants were requested to keep their knees extended and their hands overlapping each other in such a way that the middle finger of one hand was superimposed over the middle finger of the other hand. From this position, participants were requested to completely flex their trunk towards the ground with their arms and head relaxed [19]. At that moment, the interviewer measured the distance between the tip of the middle finger to the floor using a measuring tape.

Postural evaluation was performed from the frontal, right and left, and posterior views. The presence of postural disorders was recorded on the assessment sheet and included: scoliosis; anterior head; lumbar and cervical hyperlordosis; thoracic hyperkinesis and decreased spinal curvatures [20].

\section{Statistical analysis}

We performed descriptive statistics using means and standard deviations for the quantitative variables and absolute and relative frequencies for the categorical variables. Data normality was verified by the Kolmogorov-Smirnov test. The relationship between the ODI values of those who reported some level of disability and the quantitative variables was analyzed by Pearson's correlation test. The relationship between the ODI score and the categorical variables was evaluated by Student's t-test or ANOVA with Tukey post-hoc, according to the number of categories of the variable.

Finally, a multiple linear regression analysis was performed using the Backward method to identify variables related to the ODI score among individuals with some level of disability due to low back pain. Variables with $\mathrm{p}<0.20$ in the bivariate analysis were entered the model. Only those who maintained $\mathrm{p}<0.05$ remained in the final model. We considered a significance level of $5 \%$ and confidence intervals of $95 \%$ at all stages. We used the Statistical Package for the Social Sciences (SPSS) for Windows version 20.0 for these analyses.

\section{Results}

We evaluated 97 military police officers of the $8^{\text {th }}$ Military Police Battalion of Rio Grande do Norte and the sample characteristics are described in Table 1.

Table 1 - Sample characteristics $(n=97)$

\begin{tabular}{|c|c|}
\hline Variables & Mean $( \pm$ SD) or N (\%) \\
\hline Age (years) & $39.30( \pm 5.33)$ \\
\hline \multicolumn{2}{|l|}{ Education } \\
\hline Up to high school & $46(47.4 \%)$ \\
\hline More than high school & $51(52.6 \%)$ \\
\hline Family Income (Brazilian Reals) & $4.667 .34( \pm 2.518 .13)$ \\
\hline \multicolumn{2}{|l|}{ Ethnicity } \\
\hline White & 31 (34.1\%) \\
\hline Brown & $53(58.2 \%)$ \\
\hline Black & $4(4.4 \%)$ \\
\hline Yellow & $3(3.3 \%)$ \\
\hline BMI (Kg/m2) & $28.06( \pm 3.04)$ \\
\hline \multicolumn{2}{|l|}{ Postural disorders } \\
\hline Yes & $11(11.3 \%)$ \\
\hline No & $86(88.7 \%)$ \\
\hline Distance fingertip-to-floor (cm) & $13.55( \pm 8.85)$ \\
\hline \multicolumn{2}{|l|}{ Function } \\
\hline Patrol car & $63(64.9 \%)$ \\
\hline Commander & $8(8.2 \%)$ \\
\hline Administrative Function & $8(8.2 \%)$ \\
\hline Police custodian & $7(7.2 \%)$ \\
\hline Others & $11(11.3 \%)$ \\
\hline Years of professional work (years) & $15.04( \pm 6.35)$ \\
\hline \multicolumn{2}{|l|}{ Most prevalent work position } \\
\hline Sitting & $45(46.4 \%)$ \\
\hline Standing & $17(17.5 \%)$ \\
\hline Both equally & $35(36.1 \%)$ \\
\hline \multicolumn{2}{|l|}{ Leave of absence } \\
\hline Yes & $16(16.5 \%)$ \\
\hline No & $81(83.5 \%)$ \\
\hline
\end{tabular}

Note: BMl: Body Mass Index.

Table 2 shows the results regarding the prevalence and intensity of low back pain before and after a work shift. Most police officers reported pain at the time of the interview, even before their work shift. We observed 
an increase in the proportion of police officers reporting low back pain after work. The pain intensity was also higher after than before starting the work shift.

Table 2 - Prevalence and intensity of low back pain before and after a work shift $(\mathrm{n}=97)$

\begin{tabular}{|c|c|c|}
\hline Variables & \multicolumn{2}{|c|}{ Mean (SD) or $n(\%)$} \\
\hline \multicolumn{3}{|l|}{ Before the work shift } \\
\hline \multicolumn{3}{|l|}{ Low back pain } \\
\hline Yes & \multicolumn{2}{|l|}{$57(58.8 \%)$} \\
\hline No & \multicolumn{2}{|l|}{$40(41.2 \%)$} \\
\hline Level of pain (Numerical Scale) & \multicolumn{2}{|l|}{$2.00(2.12)^{\star}$} \\
\hline \multicolumn{3}{|c|}{ After the work shift } \\
\hline \multicolumn{3}{|l|}{ Low back pain } \\
\hline Yes & \multicolumn{2}{|l|}{$87(89.7 \%)$} \\
\hline No & \multicolumn{2}{|l|}{$10(10.3 \%)$} \\
\hline Level of pain (Numerical Scale) & \multicolumn{2}{|l|}{$4.34(2.51)^{\star}$} \\
\hline Mean increase in pain intensity & \multicolumn{2}{|l|}{$2.34(1.54)$} \\
\hline \multicolumn{3}{|c|}{$\begin{array}{l}\text { Note: *Pain level after work shift was statistically higher than befor } \\
\text { work shift ( } p<0.001 \text { in paired t test). }\end{array}$} \\
\hline \multicolumn{3}{|c|}{$\begin{array}{l}\text { Regarding the interference of low back pain on daily } \\
\text { living activities, } 82.5 \%(\mathrm{~N}=80 \text { ) of the respondents } \\
\text { reported some impairment in performing their activities } \\
\text { because of pain. Of these, } 76.3 \%(\mathrm{~N}=61 \text { ) were classified } \\
\text { as having mild disability (ODI - } 0 \text { to } 20 \% \text { ) and } 23.7 \% \text { (N } \\
=19 \text { ) as having moderate disability (ODI - } 21 \% \text { to } 40 \% \text { ). } \\
\text { Table } 3 \text { shows the correlation between the ODI score } \\
\text { and the quantitative variables of the study. We found } \\
\text { a significant positive correlation among ODI and the } \\
\text { following variables: age, years of professional work, BMI } \\
\text { and pain level before and after the work shift. }\end{array}$} \\
\hline \multicolumn{3}{|c|}{$\begin{array}{l}\text { Table } 3 \text { - Correlation between the Owestry Disability Index (ODI) } \\
\text { score and the quantitative variables for police officers who pres- } \\
\text { ent some level of disability due to low back pain }(n=80)\end{array}$} \\
\hline \multirow[t]{2}{*}{ Variables } & ODI Sc & \\
\hline & $\mathrm{R}$ & $p$ value \\
\hline Age & 0.39 & $<0.001$ \\
\hline Family income & 0.08 & 0.49 \\
\hline Years of professional work & 0.22 & 0.05 \\
\hline BMI & 0.22 & 0.04 \\
\hline Distance fingertip-to-floor & -0.14 & 0.21 \\
\hline Level of pain before work shift & 0.64 & $<0.001$ \\
\hline Level of pain after work shift & 0.68 & $<0.001$ \\
\hline
\end{tabular}

Note: BMI - Body Mass Index.
Table 4 presents the ODI mean scores according to the categories of the qualitative variables for the police officers who presented some level of disability identified by the scale. No significant differences were found between the variables under study.

Table 4 - Means and standard deviations of the ODI scores according to the study's categorical variables for participants with some level of disability due to low back pain $(n=80)$

\begin{tabular}{|c|c|c|}
\hline Variables & $\begin{array}{l}\text { ODI Score } \\
\text { Mean (SD) }\end{array}$ & $p$-value \\
\hline \multicolumn{3}{|l|}{ Education } \\
\hline Up to high school & 7.54 (5.42) & \\
\hline More than high school & $6.66(5.09)$ & \\
\hline Ethnicity & & 0.69 \\
\hline White & $7.04(5.17)$ & \\
\hline Brown & $7.14(5.58)$ & \\
\hline Black & $10.66(0.57)$ & \\
\hline Yellow & $5.50(3.53)$ & \\
\hline Function & & 0.38 \\
\hline Patrol car & $6.30(4.37)$ & \\
\hline Commander & $9.71(8.24)$ & \\
\hline Administrative Function & $9.28(6.39)$ & \\
\hline Police custodian & $7.00(3.89)$ & \\
\hline Others & $7.62(4.92)$ & \\
\hline Postural disorders & & 0.16 \\
\hline Yes & $6.76(4.78)$ & \\
\hline No & $9.33(7.93)$ & \\
\hline $\begin{array}{l}\text { Most prevalent work } \\
\text { position }\end{array}$ & & 0.35 \\
\hline Sitting & $6.25(4.47)$ & \\
\hline Standing & $8.50(5.72)$ & \\
\hline Both equally & $7.44(5.93)$ & \\
\hline Leave of absence & & 0.14 \\
\hline Yes & $10.14(4.99)$ & \\
\hline No & $6.39(5.07)$ & \\
\hline
\end{tabular}

Table 5 presents the results of the multiple linear regression analysis to evaluate the predictive variables of the ODI score among military police officers who present some level of disability. The variables age, postural changes and pain level after work remained in the final model. According to the results, each year of age increases the ODI score by 0.31 ; not having postural changes reduces the score by almost 3 points; and each 
increased point in the self-reported pain level after the work shift increases the ODI score by 1.32 .

Table 5 - Results of the multiple linear regression analysis (backward method) with variables that remained related to the ODI score for participants with some level of disability $(n=80)$

\begin{tabular}{llll}
\hline \multicolumn{4}{l}{ ODI Score } \\
Variables & $\boldsymbol{\beta}$ & IC (95\%) & p-value \\
Age & 0.31 & $0.146: 0.469$ & $<0.001$ \\
Postural Disorders & & & \\
Yes & -2.81 & $-5.479:$ & 0.04 \\
No & 0 & & \\
$\begin{array}{l}\text { Level of pain after the } \\
\text { work shift }\end{array}$ & 1.32 & $0.888: 1.576$ & $<0.001$ \\
\hline
\end{tabular}

\section{Discussion}

A high prevalence (58.8\%) of low back pain was observed before the work shift. This finding corroborates the cross-sectional studies performed by Santos [21] and Bernardi et al. [22], which evidenced a prevalence of $84.61 \%$ and $63.6 \%$ of low back pain in military police officers, respectively [21,22].

After the work shift, the prevalence of pain was even higher, reaching $89.7 \%$. This possibly happened due to the physical effort required during the work day and the repetitive activities followed by several hours in an orthostatic position or in the interior of the police car $[12,23]$. Arts [9] showed that the wear on the seats caused by the time of use modifies the support surface of the thoracolumbar region, favoring the adoption of compensatory positions and the onset of low back pain.

In addition to the operational activity, a police officer often performs administrative activities [7-9]. A study by Santos et al. compared both groups and concluded that administrative police officers have more points that are painful in the lumbar region (76\%) than operational police (45\%). Barros etal. found similar results in which individuals with seated labor functions had a higher incidence of low back pain [24,25].

This fact can be explained by the long stay in the sitting position, which in turn leads to reduced muscle flexibility and mobility, as well as fatigue of the spinal extensor muscles. Such biomechanical disorders are considered important etiological factors for the development of low back pain [26].

Regarding the impact of pain on daily living activities (ADLs), 82.5\% of respondents reported some level of disability, thus showing how this condition has a negative impact on quality of life.

In the linear regression analysis, the level of low back pain after the work shift remained significantly associated with higher ODI scores, as well as the age and the presence of postural disorders. The relationship between higher level of impairment in ADLs due to low back pain and age was already an expected result, since both the prevalence, intensity of pain and the difficulty to perform ADLs worsen with advancing age. A study conducted with military police in the state of Bahia in 2013 showed that more than $50 \%$ of police officers from the age of 35 present complaints in the lumbar region, and that the pain symptoms increase approximately $15 \%$ for every 5 years of service time, with an even higher prevalence after 26 years of service time [12].

The natural wear and tear of the spine with advancing age and the increase in incidence due to the time of service represent the sum of the factors favoring the condition [12], in military police activity, the individual is exposed to many factors that may interfere with your health. There are several areas of activity of the police: some carry out internal functions, such as administrative activities; others make ostensive policing by staying for many hours on foot and using equipment, which, together with working conditions, can column overload [27]. This reinforces the need for including physical activities in the military police routine to reduce the effects of age on the structure and function of the lumbar spine, since physical activity is cited as an instrument for recovery, maintenance and health promotion [28].

In relation to the presence of postural disorders, Mathias et al. [29] found similar results when reporting that $63.89 \%$ of those with lumbar hyperlordosis presented low back pain [25]. The association between maintained inadequate postures when performing domestic and professional activities may increase the likelihood of low back pain [30].

This paper presents some limitations. The crosssectional design limits causal inferences and longitudinal studies are necessary to know if low back pain leads to impairment in ADLs or if the limitation in ADLs contributed to the appearance of low back pain in this sample. The presence of low back pain and disability level were evaluated by self-report which can generate bias, since the police can underestimate or overestimate the pain and the corresponding disability. Although the sample was recruited through convenience sampling, it can be considered as representative since it presents similar characteristics to the total population of the 
$8^{\text {th }}$ MPB in relation to the mean age, distribution of functions and average time as a police officer.

\section{Conclusion}

There is a high prevalence of low back pain with associated impairment in daily living activities in military police officers. The presented data reinforce the need to consider low back pain as a public health problem that affects the whole population, and especially police officers given the particularities of their work, as demonstrated by these findings. Preventive measures to reduce the onset and/or worsening of low back pain in this population during the performance of their duties are necessary to improve the quality of life and reduce costs with future possible absence of work.

\section{References}

1. Bade M, Cobo-Estevez M, Neeley D, Pandya J, Gunderson T, Cook C. Effects of manual therapy and exercise targeting the hips in patients with low-back pain-A randomized controlled trial. J Eval Clin Pract. 2017;23(4):734-40.

2. Lee SY, Cho NH, Jung YO, Seo YI, Kim HA. Prevalence and Risk Factors for Lumbar Spondylosis and Its Association with Low Back Pain among Rural Korean Residents. J Korean Neurosurg Soc. 2017;60(1):67-74.

3. Brazil AV, Ximenes AC, Radu AS, Fernades AR, Appel C, Maçaneiro CH, et al. Diagnóstico e tratamento das lombalgias e lombociatalgias. Rev Bras Reumatol. 2004;44(6):419-25.

4. Bagraith KS, Strong J, Meredith PJ, McPhail SM. Selfreported disability according to the International Classification of Functioning, Disability and Health low back pain core set: Test-retest agreement and reliability. Disabil Health J. 2017;10(4):621-6.

5. Kamalikhah T, Morowatisharifabad MA, RezaeiMoghaddam F, Ghasemi M, Gholami-Fesharaki M, Goklani S. Alexander Technique Training Coupled With an Integrative Model of Behavioral Prediction in Teachers With Low Back Pain. Iran Red Crescent Med J. 2016;18(9):e31218.

6. Nascimento PR, Costa LO. Prevalência da dor lombar no Brasil: uma revisão sistemática. Cad Saude Publica. 2015;31(6):1141-56.
7. Ministério da Saúde, Secretaria de Políticas Públicas. Programa Nacional da Promoção de Atividade Física "Agita Brasil": Atividade física e sua contribuição à qualidade de vida. Rev Saude Publica. 2002;36(2):254-6.

8. Campos-Fumero A, Delclos GL, Douphrate DI, Felknor AS, Vargas-Prada S, Serra C, et al. Low back pain among office workers in three Spanish-speaking countries: findings from the CUPID study. Inj Prev. 2017;23(3):158-64.

9. Arts JG. Low Back Pain in Police Officers [master's thesis]. Allendale, MI: Grand Valley State University; 2006.

10. Mendelek F, Kheir RB, Caby I, Thevenon A, Pelayo P. On the quantitative relationships between individual/ occupational risk factors and low back pain prevalence using nonparametric approaches. Joint Bone Spine. 2011;78(6):619-24.

11. Favacho FB, Rosa MSS. Aptidão física relacionada a saúde de policiais militares. Universidade Federal do Pará; 2012 [cited 2018 Feb 18]. Available from: <https:// tinyurl.com/ybeudop2>.

12. Tavares Neto A, Faleiro TB, Moreira FD, Jambeiro JS, Schulz RS. Lombalgia na atividade policial militar: análise da prevalência, repercussões laborativas e custo indireto. Rev Baiana Saude Publica. 2013;37(2):365-74.

13. Minayo MCS, Assis SG, Oliveira RVC. Impacto das atividades profissionais na saúde física e mental dos policiais civis e militares do Rio de Janeiro (RJ, Brasil). Cienc Saude Coletiva. 2011;16(4):2199-2209.

14. Vasconcelos IC. Estudo ergonômico do colete a prova de balas utilizado na atividade policial [master's thesis]. Bauru: Universidade Estadual Paulista; 2007.

15. Vigatto R, Alexandre NM, Correa Filho HR. Development of a Brazilian Portuguese Version of the Oswestry Disability Index: cross-cultural adaptation, reliability, and validity. Spine (Phila Pa 1976). 2007;32(4):481-6.

16. Fairbank JC, Couper J, Davies JB, O'Brien JP. The Oswestry low back pain disability questionnaire. Physiotherapy. 1980;66(8):271-3.

17. Fortunato JGS, Furtado MS, Hirabae LFA, Oliveira JA. Escala de dor em paciente crítico: Uma revisão integrativa. Med HUPE-EURJ. 2013;12(3):110-7. 
18. Carvalho EM, Paula Jr AR, Oliveira MA. Avaliação da flexibilidade em adultos jovens antes e após tratamento através do método de reeducação postural global. XIII Encontro Latino Americano de Iniciação Científica e IX Encontro Latino Americano de Pós-Graduação Universidade do Vale do Paraíba; 2009 Oct 16-17; São José dos Campos. São José dos Campos: Universidade do Vale do Paraíba; 2009.

19. Magnusson SP, Simonsen EB, Aagaard P, Boesen J, Johannsen F, Kjaer M. Determinants of musculoskeletal flexibility: viscoelastic properties, cross-sectional area, EMG and stretch tolerance. Scand J Med Sci Sports. 1997;7(4):195-202.

20. Ferreira EAG. Postura e controle postural: desenvolvimento e aplicação de método quantitativo de avaliação [dissertation]. São Paulo: Universidade de São Paulo; 2005.

21. Santos HCB. Incidência de dores e incômodos lombares dos motociclistas da ROTAM da Polícia Militar da Paraíba [undergraduate thesis]. Campina Grande: Universidade Estadual da Paraíba; 2014.

22. Bernardi MC, Leyva-Nápole RA. A presença da DORT em Policiais Militares Rodoviários do Estado de São Paulo. Congresso de Fisioterapia Intercobraf; 2006 Oct 12-14; Santos. Rio de Janeiro: COBRAF; 2006.

23. Paulo LFL, Andrade MFAM, Bordim Neto C, Hirota VB, Adami F. Prevalência de dor em alunos da academia de Policia Militar do Barro Branco. Rev Delfos. 2014;1(1).
24. Reis PF, Moro ARP, Contijo LA. A importância da manutenção de bons níveis de flexibilidade nos trabalha dores que executam suas atividades laborais sentados. Rev Prod Online. 2003;3(3).

25. Barros SS, Angelo RCO, Uchoa EPBL. Lombalgia ocupacional e a postura sentada. Rev Dor. 2011;12(3):226-30.

26. Santos MC, Krueger E, Neves EB. Distribuição anatômica das queixas álgicas de Policiais Militares do Paraná. XXIV Congresso Brasileiro de Engenharia Biomédica; 2014 Oct 13-17; Uberlândia: Universidade Federal de Uberlândia, SBEB; 2014.

27. Fraga CK. Peculiaridades do trabalho de policial militar. Textos e Contextos. 2006; 5(2):1-19.

28. Pacheco FJA, Maurício MF. Frequência da atividade física executada por policiais militares integrantes da ROTAM - PMES [undergraduate thesis]. Universidade Federal do Espírito Santo, Centro de educação física e desporto. 2014.

29. Matias CN, Damázio CM. Correlação entre a prevalência de dor e alterações posturais em trabalhadores de uma fábrica de móveis. Rev Bras Cien Saude. 2009;7(20):30-8.

30. Marques NR, Hallal CZ, Gonçalves M. Características biomecânicas, ergonômicas e clínicas da postura sentada: uma revisão. Fisioterapia e Pesquisa. 2010; 17 (3): 270-6.

Received in 08/20/2017

Recebido em 20/08/2017

Recibido en 20/08/2017

Approved in 02/05/2018 Aprovado em 05/02/2018 Aprobado en 05/02/2018 